\title{
Short Communication: Diversity and community structure of trees in two forest types in Mt. Apo Natural Park (MANP), Philippines
}

\author{
FLORENCE ROY P. SALVAÑA ${ }^{1,3,4, \boldsymbol{v}}$, CHRISTIE KAYE C. LOPEZ ${ }^{2}$, CHERIE C. MANGAOANG ${ }^{1}$, \\ BRYAN LLOYD P. BRETAÑA ${ }^{1}$ \\ ${ }^{1}$ Department of Biological Sciences, College of Arts and Sciences, University of Southern Mindanao. Kabacan, Cotabato, Philippines. \\ •email: rdsalvana@usm.edu.ph \\ ${ }^{2}$ Kidapawan Doctor's College. Kidapawan City, Cotabato, Philippines \\ ${ }^{3}$ Graduate School, University of the Philippines Los Baños. Laguna, Philippines \\ ${ }^{4}$ Philippine Council for Agriculture, Aquatics and Natural Resources Research and Development (DOST-PCAARRD), Brgy. Timugan, Los Baños, \\ Laguna, Philippines
}

Manuscript received: 3 April 2019. Revision accepted: 3 June 2019.

\begin{abstract}
Salvaña FRP, Lopez CKC, Mangaoang CC, Bretaña BLP. 2019. Short Communication: Diversity and community structure of trees in two forest types in Mt. Apo Natural Park (MANP), Philippines. Biodiversitas 20: 1794-1801. A forest ecosystem is the basic ecological unit that exists as a habitat for a community of both native and introduced organisms. It is the limited number of reliable information on the diversity and community structure of tree species in one of the Philippines' protected landscape, Mt. Apo Natural Park (MANP), that initiates this study. The present study was carried out to determine species diversity and community structure including seedlings, saplings and large trees of two forest types, namely tropical lowland evergreen rainforest and tropical lower montane rainforest. Two one-kilometer transects were established in each forest types. Each transect was divided into five sampling points. A total of 67 tree species belonging to 29 families were identified from both forest types. Species richness was higher in tropical lowland evergreen rainforest compared to tropical lower montane rainforest. Relative abundance showed that among the identified families, Dipterocarpaceae and Moraceae have the highest abundance which is mostly present in the two forest types. This was followed by Meliaceae and Myrtaceae. The two forest types were satisfactory at community level having large number of seedlings compared to saplings and trees. Based on this, the two forest types, dominated by seedlings, are actively regenerating.
\end{abstract}

Keywords: Community structure, diversity, forest types, MANP, trees

\section{INTRODUCTION}

Tropical forests are the richest biological communities on earth and have been recognized as important in the balance of global biodiversity (Myers et al. 2000; Baraloto et al. 2013). Djuikouo et al. (2010) stated that these forest types are subject of several studies to enhance understanding of the role they play in sustainable development, climate change, and floristic biodiversity. They provide many services such as species conservation, prevention of soil erosion and preservation of habitat for plants and animals (Armenteras et al. 2009). Assessment of forest community structure is a prerequisite to describe various ecological processes and to model forest functional groups and dynamics (Elourard et al. 1997). Knowledge of floristic composition and structure of forest reserves is useful in distinguishing important elements of plant diversity, protecting threatened and economically important species and monitoring the state of reserves (Tilman 1988; Ssegawa and Nkuutu 2006). Diversity studies on forest biome are significant indicators that allow appreciating links between the richness and abundance of individual trees which in turn reflects the degree of heterogeneity or stability of vegetation (Trichon 1997).
Typically, tropical rainforests are dominated by trees. The population structure of tree species reflects its biological and ecological characteristics. Vertical stratification characteristic of forests is due to the presence of large and mature trees. They generally constitute the canopy and emergent layers of forest ecosystem. Also, these trees, at considerable size, also expands the ecological niche of forests thereby expanding habitat for other organisms (Taubert et al. 2015). Inventory of tree species diversity also provides information that represents a vital tool to enhance our ability to maximize biodiversity conservation (Baraloto et al. 2013). Information from this provides a valuable reference for forest assessment and improves our knowledge in identification of ecologically useful species for sustainability of forest biodiversity. In addition, the success of regeneration can be predicted on the basis of current population structure, growth, and fecundity (Guedje et al. 2013). The presence of sufficient number of seedlings, saplings and young trees indicates regeneration (Saxena and Singh 1984), which is frequently influenced by the interactions and physical factors in the community.

Philippines is dominated by tropical rainforest across different islands. These rainforests are known to house 
native species of flora and fauna. More often than not, most of these forests are within protected areas and landscapes. Some of the well-known tropical forests can be found in the southern part, like Mt. Apo Natural Park (MANP). It is a protected area in the south-central part of Mindanao, Philippines under the National Integrated Protected Areas System-Republic Act No. 9237 in 2003. It is the highest mountain in the Philippines with an altitude of 2,954 masl. The protected landscape is also included in the UN List of National Parks and Equivalent Reserves and acknowledged as an ASEAN Heritage Site. MANP is a home of several endemic and threatened species of flora and fauna especially for the critically endangered Philippine Eagle (Pithecophaga jefferyi). It is inhabited by several indigenous tribes and a tourist attraction. Forest and habitat degradation are prevalent as forest lands are converted for agricultural use and human settlement. Illegal tree cutting for timber and charcoal production is also an additional threat to forest health which contributes to a serious net forest loss. Recently, due to the extreme effects of drought, massive fire eats up an estimated 100 ha of forests in Mt. Apo Natural Park. Some affected areas include lowland montane forest near boulders and mini-forest of Lake Venado. Diversity and community structure of trees can be affected by these threats and studies dealing with this aspect in the area are scarce.

Tropical lowland evergreen rainforest, or commonly known as Dipterocarp forest, is primarily dominated by member of Dipterocarpaceae and located up to 1000 masl. Other species common to this forest type are rattans and lianas. It is characterized by a short dry season and relatively uniform rainfall. On the other hand, tropical lower montane rainforests are usually located from 750 to 1,500 masl. Most common species include Lithocarpus, Elaeocarpus, Litsea, Neolitsea, Syzygium_and some shrubs of Rubiaceae and Acanthaceae (Fernando et al. 2008).

MANP has three forest types including tropical lowland evergreen rainforest, tropical lower montane rainforest, and tropical semi-evergreen rainforest. The first two forest types were considered since these are more prone to threats of deforestation. These two forest types constitute a large portion of MANP in which continuous reduction has been observed. Also, these forest types are usually located near human settlement. In the present era, various tropical forests across the globe are facing the same threats. The presence of endemic tree species in these forests necessitates this assessment. There have been a considerable number of species got extinct or threatened without the opportunity to be described and assessed. The main goal of this research is to determine the diversity and community structure of trees in MANP which serves as a baseline in crafting and enforcing policies on forest conservation. Community structure can also depict regeneration capacity of these forest types which was also discussed in this study.

\section{MATERIALS AND METHODS}

\section{Study site}

Mt. Apo Natural Park (MANP), Philippines is a mountainous landscape with an elevation of $2,954 \mathrm{~m}$ above sea level comprises 54,974.87 ha that lies between $6^{\circ} 41 \mathrm{~N}$ and $7^{\circ} 07$ latitude and between $125^{\circ} 27^{\prime} \mathrm{E}$ longitude. MANP is known as one of the most ecologically rich mountains in the region. Due to the diversity of its landscape influenced by its climate, soil, rock formations, slant, and drainage, a wide variety of plants grow and adapt. Hundreds of endemic species of plants, including rare and threatened species, have been recorded on different forest types which includes Lithocarpus submonticolus, Peperomia elmeri, Nepenthes copelandii, Aglaia apoena, Plectomia elmerii and the well-known Euanthe sanderiana (Figure 1).

\section{Establishment of sampling plots}

Two forest types were considered, tropical lowland evergreen rainforest and tropical lower montane rainforest. Forest classification was based on the classification of Fernando et al. (2008). There were two one- kilometer transects established in each forest type between 940 to 1277 masl. Center point circular plot method (Kent and Coker 1992) was used wherein a circular plot with a radius of $20 \mathrm{~m}$, was established in each sampling points. Each circular plot was divided into 4 sections which were used as replicates (Figure 2).

\section{Data collections}

Pre-identification of samples was done on-site. This was done through the use of pictorial guide, monographs, lexicons, and key guides: Botanical Identification Handbook on Philippine Dipterocarps by Rojo and Aragones (1997) and Lexicon of Philippine Trees by Rojo (1992). Samples identification was confirmed by local expert. Identification was based on both vegetative, which includes leaf and bole characteristics, and if present, reproductive parts, which include flower and fruit characteristics. Classification of individual was based on the measurement of dbh/ stem girth which include (Rawat 2014): (i) mature tree- > 31cm; (ii) sapling-11-30cm; and (iii) seedling- $<11 \mathrm{~cm}$. Plant height was also measured and was also used as basis for classification (Gavin and Peart, 1997). Assessment of environmental data was not done since this study focused on diversity and community structure of trees.

\section{Data analysis}

Species richness and relative abundance were calculated. Species richness is the number of species per transect in each forest type. Relative abundance was measured using the number of individuals per species and total number of species identified. 


\section{RESULTS AND DISCUSSION}

The results showed that a total of sixty-seven (67) species of trees (Table 1) were identified in two forest types in MANP belonging to twenty-nine (29) families namely: Actinidiaceae, Anacardiaceae, Annonaceae, Araliaceae, Bignoniaceae, Cannabaceae, Clusiaceae,
Combretaceae, Dilleniaceae, Dipterocarpaceae, Euphorbiaceae, Fabaceae, Fagaceae, Lamiaceae, Lauraceae, Lecythidaceae, Lythraceae, Malvaceae, Melastomataceae, Meliaceae, Moraceae, Myrtaceae, Phyllanthaceae, Piperaceae, Primulaceae, Rubiaceae, Sapindaceae, Theaceae and Urticaceae.

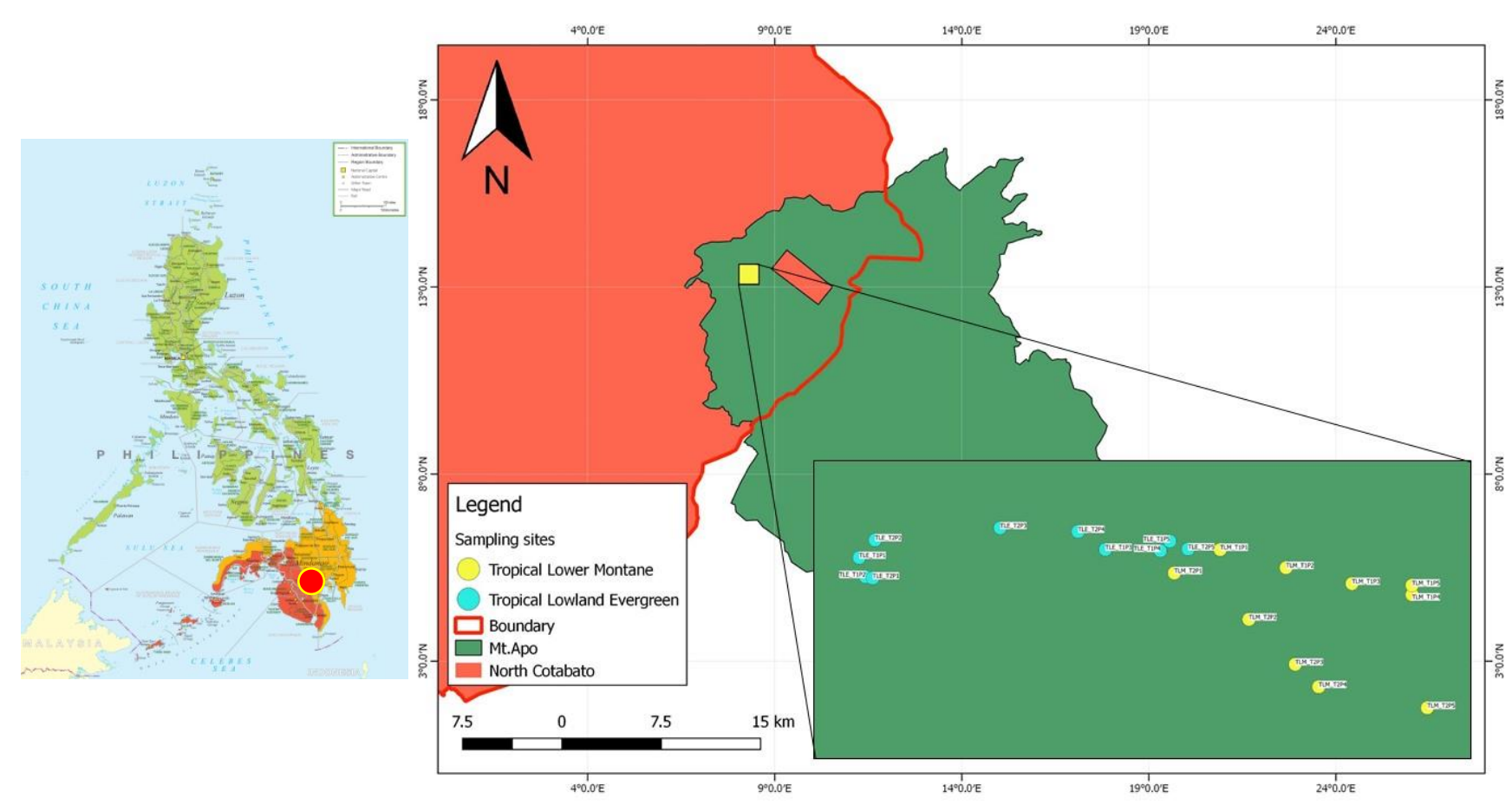

Figure 1. Study site showing sampling points in Mt. Apo Natural Park (MANP), Philippines

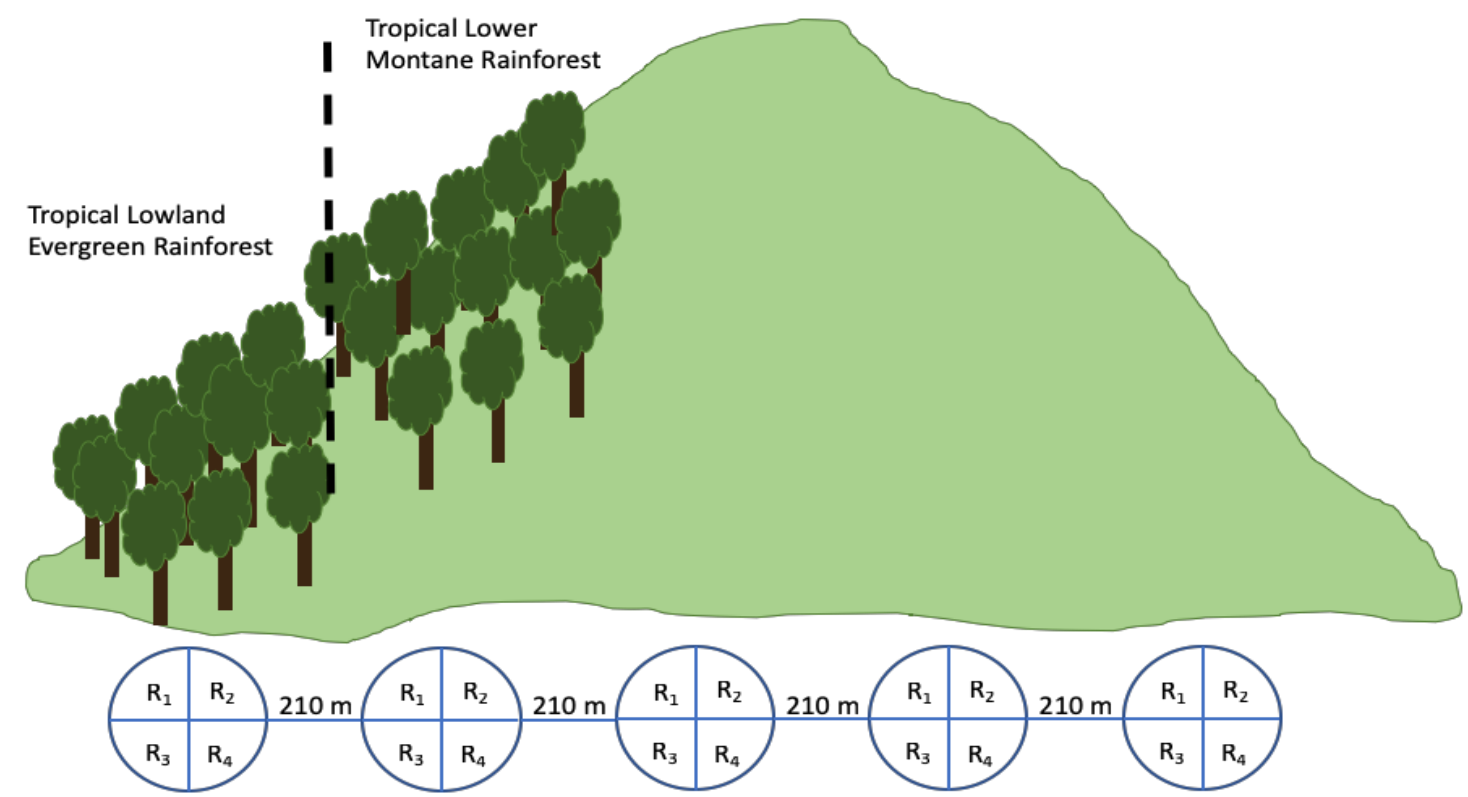

Figure 2. Establishment of center point circular method 
Table 1. List of identified species of trees in two forest types of MANP, Philippines

\begin{tabular}{|c|c|c|c|c|}
\hline Family & Species & Common name & $\begin{array}{c}\text { Tropical } \\
\text { lowland } \\
\text { evergreen } \\
\text { rainforest }\end{array}$ & $\begin{array}{c}\text { Tropical } \\
\text { lower } \\
\text { montane } \\
\text { rainforest }\end{array}$ \\
\hline Actinidiaceae & Saurauia $\mathrm{sp}$. & Saurauia & $\sqrt{ }$ & $\sqrt{ }$ \\
\hline Anacardiaceae & Semecarpus philippinensis L. & Kamiring & $\sqrt{ }$ & $\sqrt{ }$ \\
\hline \multirow[t]{2}{*}{ Annonaceae } & Annona reticulata $\mathrm{L}$. & Custard apple & $\sqrt{ }$ & \\
\hline & Cananga odorata (Lam.) Hook. F. \& Thomson & Langilan & & $\sqrt{ }$ \\
\hline Araliaceae & Polyscias nodosa (Blume) Seem. & Malapapaya & $\sqrt{ }$ & \\
\hline Bignoniaceae & Spathodea campanulata Beauv. & African tulip & $\sqrt{ }$ & \\
\hline \multirow[t]{2}{*}{ Cannabaceae } & Trema orientalis (L.) Blume & Anabiong & $\sqrt{ }$ & \\
\hline & Celtis luzonica Warb. & Anonang & $\sqrt{ }$ & $\sqrt{ }$ \\
\hline \multirow[t]{2}{*}{ Clusiaceae } & Calophyllum blancoi. $\mathrm{Pl} \& \mathrm{Tr}$. & Bitangol & $\sqrt{ }$ & $\sqrt{ }$ \\
\hline & Garcinia dives Pierre & Brindleberry & $\sqrt{ }$ & \\
\hline Combretaceae & Terminalia calamansanai (Blanco) Rolfe & Anarep & $\sqrt{ }$ & $\sqrt{ }$ \\
\hline Dilleniaceae & Dillenia philippinensis Rolfe & Katmon & $\sqrt{ }$ & $\sqrt{ }$ \\
\hline \multirow[t]{9}{*}{ Dipterocarpaceae } & Anisoptera aurea Foxw. & Dagang & $\sqrt{ }$ & \\
\hline & Dipterocarpus grandiflorus (Blanco) Blanco & Apitong & $\sqrt{ }$ & $\sqrt{ }$ \\
\hline & Shorea almon Foxw. & Almon & $\sqrt{ }$ & $\sqrt{ }$ \\
\hline & Shorea contorta Vidal. & White lauan & $\sqrt{ }$ & $\sqrt{ }$ \\
\hline & Shorea negrosensis Foxw. & Red lauan & $\sqrt{ }$ & $\sqrt{ }$ \\
\hline & Shorea palosapis (Blanco) Merr. & Mayapis & $\sqrt{ }$ & $\sqrt{ }$ \\
\hline & Shorea polysperma (Blanco) Merr. & Tanguile & $\sqrt{ }$ & $\sqrt{ }$ \\
\hline & Parashorea malaanonan (Blanco) Merr. & Bagtikan & $\sqrt{ }$ & $\sqrt{ }$ \\
\hline & Shorea guiso (Blanco) Blume & Guijo & & $\sqrt{ }$ \\
\hline \multirow[t]{3}{*}{ Euphorbiaceae } & Homolanthus populifolius Graham & Malabalante & & $\sqrt{ }$ \\
\hline & Macaranga tanarius (L.) Mull.Arg. & Parasol leaf tree & $\sqrt{ }$ & $\sqrt{ }$ \\
\hline & $\begin{array}{l}\text { Melanolepis multiglandulosa (Reinw. ex Blume) } \\
\text { Rchb.f. \& Zoll. }\end{array}$ & Alim & $\sqrt{ }$ & \\
\hline Fabaceae & Intsia bijuga (Colebr.) O. Ktze. & Ipil & $\sqrt{ }$ & $\sqrt{ }$ \\
\hline \multirow[t]{4}{*}{ Fagaceae } & Lithocarpus apoensis (Elmer) Rehd. & Apo oak & $\sqrt{ }$ & \\
\hline & Lithocarpus bennettii (Miq.) Rehder & Pangnan & $\sqrt{ }$ & $\sqrt{ }$ \\
\hline & Lithocarpus ovalis (Blco.) Rehd. & Lithocarpus & $\sqrt{ }$ & $\sqrt{ }$ \\
\hline & Castanopsis evansii (Elmer) & Chinquapin & $\sqrt{ }$ & $\sqrt{ }$ \\
\hline Lamiaceae & Clerodendrum quadriloculare (Blanco) Merr. & Bagawak & $\sqrt{ }$ & \\
\hline \multirow[t]{4}{*}{ Lauraceae } & Cinnamomum mercadoi Vidal & Kalingag & $\sqrt{ }$ & $\sqrt{ }$ \\
\hline & Litsea glutinosa (Lour.) C.B. Rob. & Soft bollygum & $\sqrt{ }$ & \\
\hline & Phoebe lanceolata (Nees) Nees & Puso-puso & $\sqrt{ }$ & $\sqrt{ }$ \\
\hline & Litsea sp. & Bagnolo & $\sqrt{ }$ & $\sqrt{ }$ \\
\hline Lecythidaceae & Planchonia grandis Ridl. & Billygoat Plum & $\sqrt{ }$ & \\
\hline Lythraceae & Duabanga moluccana Blume & Loktob & $\sqrt{ }$ & $\sqrt{ }$ \\
\hline Malvaceae & Diplodiscus paniculatus Turcz. & Balobo & $\sqrt{ }$ & \\
\hline Melastomataceae & Astronia cumingiana var. bicolor (Merr.) Maxwell. & Astronia blume & $\sqrt{ }$ & \\
\hline \multirow[t]{6}{*}{ Meliaceae } & Aglaia edulis (Roxb.) Wall. & Malasaging & $\sqrt{ }$ & $\sqrt{ }$ \\
\hline & Dysoxylon gaudichaudianum (Juss.) Miq. & Malugay & $\sqrt{ }$ & $\sqrt{ }$ \\
\hline & Melia sp. & & $\sqrt{ }$ & $\sqrt{ }$ \\
\hline & Swietenia macrophylla King & Big leaf mahogany & $\sqrt{ }$ & \\
\hline & Swietenia mahogani (L.) Jacq. & Small-leaved mahogany & $\sqrt{ }$ & \\
\hline & Leptospermum flavescens J. E. Smith & Tinikaran & & $\sqrt{ }$ \\
\hline \multirow[t]{9}{*}{ Moraceae } & Artocarpus blancoi Merr. & Antipolo & $\sqrt{ }$ & \\
\hline & Artocarpus heterophyllus Lam. & Jackfruit & $\sqrt{ }$ & \\
\hline & Artocarpus odoratissimus Blanco. & Marang & $\sqrt{ }$ & \\
\hline & Ficus balete Merr. & Balete & $\sqrt{ }$ & $\sqrt{ }$ \\
\hline & Ficus heteropleura Blume & Sandy-leafed fig & $\sqrt{ }$ & $\sqrt{ }$ \\
\hline & Ficus irisiana Vázquez Avila \& Berg & Weeping Fig & $\sqrt{ }$ & $\sqrt{ }$ \\
\hline & Ficus ulmifolia Lam. & Isis & $\sqrt{ }$ & \\
\hline & Ficus heteropoda Miq. & Alangas & $\sqrt{ }$ & \\
\hline & Ficus nota (Blanco.) Merr. & Tibig & $\sqrt{ }$ & $\sqrt{ }$ \\
\hline \multirow[t]{5}{*}{ Myrtaceae } & Syzygium hutchinsonii (C.B. Rob.) Merr. & Malatambis & $\sqrt{ }$ & $\sqrt{ }$ \\
\hline & Syzygium nitidum Benth. & Makaasim & $\sqrt{ }$ & $\sqrt{ }$ \\
\hline & Syzygium panduriforme (Elmer) Merr. & Lauig-lauigan & $\sqrt{ }$ & $\sqrt{ }$ \\
\hline & Syzygium cumini (L.) Skeels. & Java plum & $\sqrt{ }$ & $\sqrt{ }$ \\
\hline & Syzygium samarangense (Blume) Merr. \& L.M.Perry & Java apple & $\sqrt{ }$ & \\
\hline Phyllanthaceae & Breynia vitis-idaea (Burm.f.) C.E.C.Fisch. & Matanghipon & $\sqrt{ }$ & \\
\hline Piperaceae & Pipturus arborescens (Link) C.B. Rob. & Agandaong & $\sqrt{ }$ & $\sqrt{ }$ \\
\hline Primulaceae & Ardisia pyramidalis (Cav.) Pers. ex A. DC. & Rugrusu & $\sqrt{ }$ & \\
\hline \multirow[t]{3}{*}{ Rubiaceae } & Lasianthus tomentosus Blume & Lasianthus & $\sqrt{ }$ & $\sqrt{ }$ \\
\hline & Cinchona pubescens Vahl. & Red chinchona & $\sqrt{ }$ & \\
\hline & Amaracarpus pubescens Blume, & Amaracarpus & $\sqrt{ }$ & $\sqrt{ }$ \\
\hline Sapindaceae & Acer laurinum Hassk. & Philippine maple & $\sqrt{ }$ & $\sqrt{ }$ \\
\hline Theaceae & Camellia sp. & Wild tea & $\sqrt{ }$ & \\
\hline Urticaceae & Dendrocnide luzonensis (Wedd.) Chew & Lipang kalabaw & $\sqrt{ }$ & \\
\hline
\end{tabular}




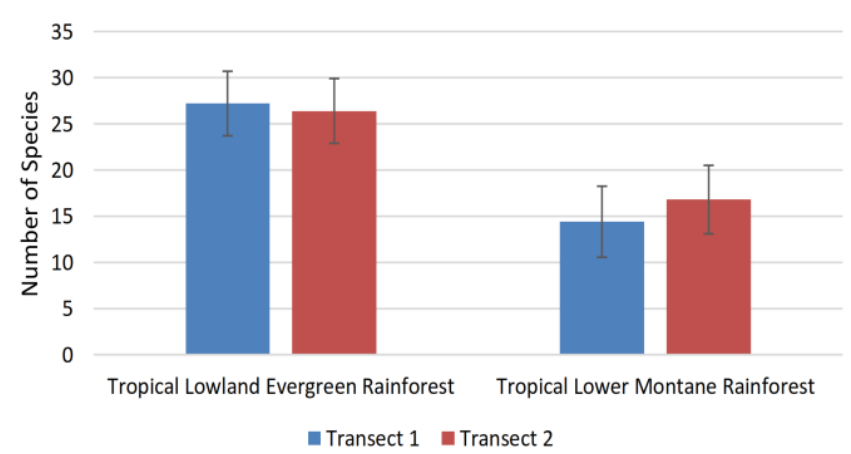

Figure 3. Species richness of trees in two forest types per transect in MANP, Philippines

In tropical lowland evergreen rainforest, 63 species belonging to 28 families were identified while 41 species belonging to 18 families in tropical lower montane rainforest (Figure 3). There are more species identified in tropical lowland evergreen rainforest identified than in tropical lower montane forest. It can be speculated that variations in altitude can be a factor in the variation of species richness. Tropical lower montane rainforests are usually located in higher elevation compared to tropical lowland evergreen forest.

Figure 4 shows the relative abundance of plant families based on the number of species identified in two transects of each forest type. Among the documented species, the most abundant families were Dipterocarpaceae and Moraceae, both with 9 species followed by Meliaceae (6 spp.) and Myrtaceae (5 spp.) in two different forest types. This result was observed in all established transects in each forest type. Other families such as Lamiaceae, Lecythidaceae, Piperaceae, and Urticaceae had the least relative abundance (1\%). The remaining families of identified species were represented by only one or two species.
The most recorded species in both forest types based on the number of individuals was Syzygium hutchinsonii with $9.35 \%(\mathrm{n}=184)$, followed by Shorea almon $8.49 \%(\mathrm{n}=167)$ and Shorea contorta $8.34 \%(\mathrm{n}=164)$. Thirty-six (36) of the sixty-seven (67) tree species were common in two forest types. Figure 5 shows the three most recorded tree species in both forest types.

Distribution of individuals in three broad strata (seedlings, saplings, trees) is depicted in Figure 6. Greater proportion of the strata were seedlings in both tropical lowland evergreen followed by saplings and then trees. This can due to the fact that the two forest types in MANP are on the status of favorable regeneration. Both the number of seedlings and samplings were higher in the tropical lowland evergreen and tropical lower montane rainforest. The two forest types were satisfactory at community level showing good regeneration capacity having large number of seedlings compared to saplings and trees. The density of trees in the tropical lower montane rainforest was higher than that in the tropical lowland evergreen forest. This is due to the fact that tropical lowland evergreen rainforest is still on the process of regeneration probably due to previous disturbances which targeted mature trees.

Greater number of species were identified in tropical lowland evergreen rainforest with Dipterocarpaceae as a well-represented family. Fernando et al. (2008) reiterated that in both forest types, tropical lower montane forest and tropical lowland evergreen forest, dipterocarps are the dominating species. Tropical lower montane forest, at their highest altitudinal limits, is covered by moss-draped bushes and epiphytes (ferns, moss, lichen, and liverworts). The higher the altitude the lower the number of species and lower canopy height is the most common generalization (WWF 1986).

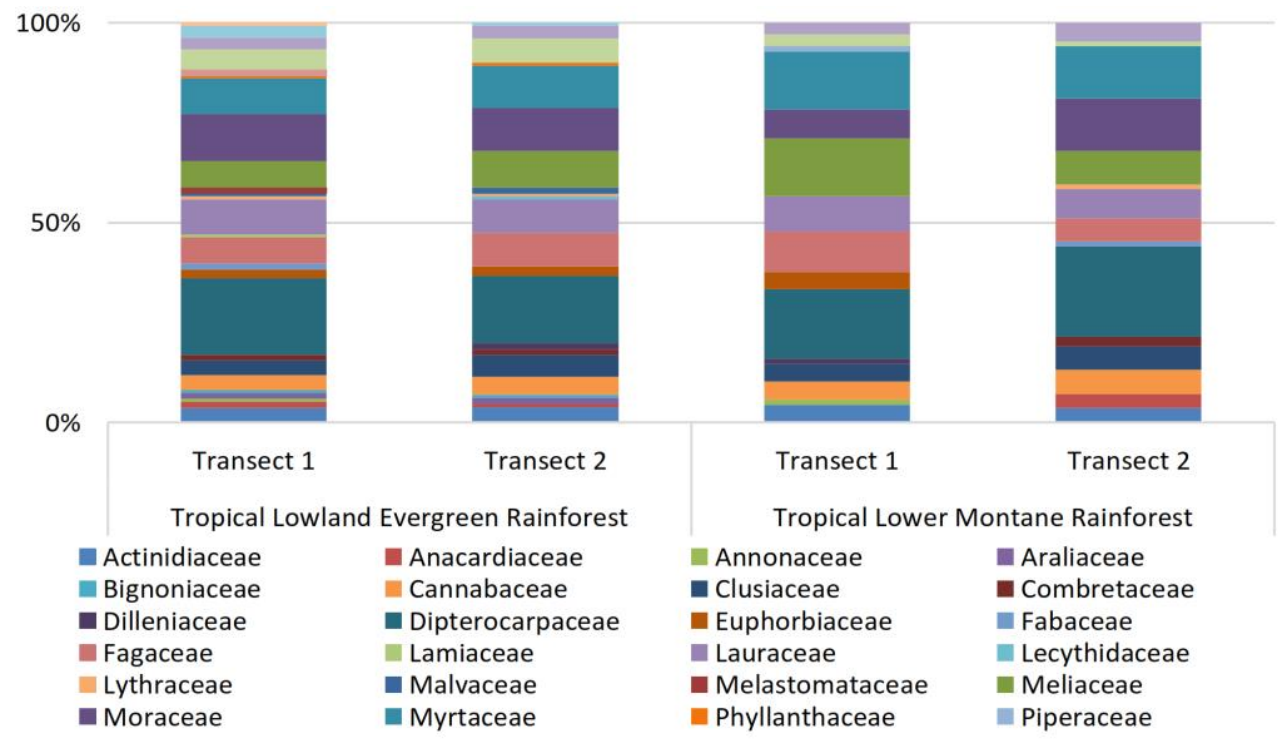

Figure 4. Relative abundance of tree species per family in MANP, Philippines 


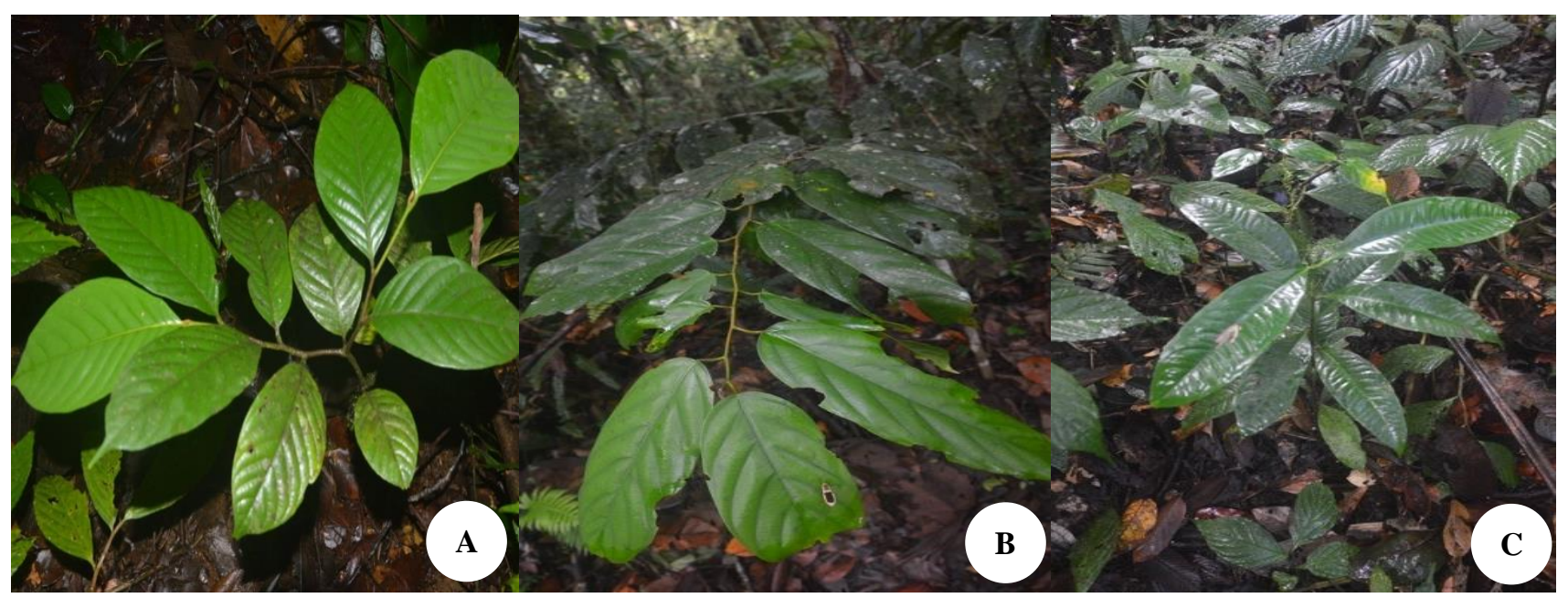

Figure 5. Most common species identified in two forest types in MANP, Philippines: A. Shorea almon; B. Shorea contorta; C. Syzygium hutchinsonii

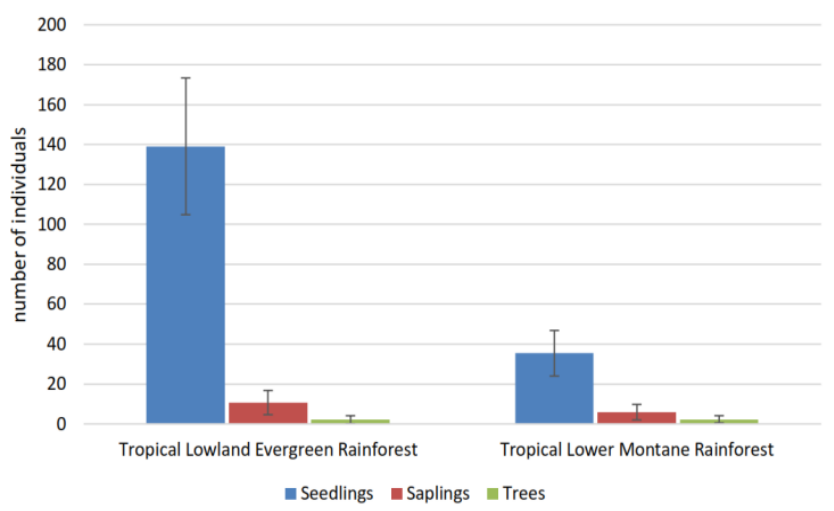

Figure 6. Number of seedlings, saplings and mature trees in two forest types in MANP, Philippines

Tropical lower montane forest is usually cooler than tropical lowland evergreen rainforest and moisture are almost constantly dripping from the swirling clouds which engulf them. In addition, cooler temperatures and relative humidity also contribute to the diversity of trees and ferns, and epiphytic plants are abundant as these plants like moisture (Mongabay 2013). Thus, the extremely low number of tree species in the tropical lower montane rainforest is due to its elevation and could be a result of few individuals undergoing transition from sapling to tree stage. This coincides with the study of Gentry (1988) wherein high species richness in tropical lowland evergreen rainforest may increase due to lower altitudinal areas and decreases with the increasing altitude.

Members of Dipterocarpaceae are usually confined mainly to areas with a mean annual rainfall exceeding $1,000 \mathrm{~mm}$ with a short duration of dry season and majority of the species occurring in areas with 2,000 mm annual rainfall (Fernando et al. 2008). These trees thrive in welldrained lands and usually can be found up to an altitude of around $1,000 \mathrm{~m}$. Dipterocarps species are found throughout the tropical regions of the world, and often considered climax species, as they dominate regions comprised of mostly primary forest (Ashton, 1988). DENR (2016) have established several monitoring plots within the same forest types and observed that most species are under family Dipterocarpaceae like species of Shorea and Parashorea which confirms the result of this study. Particularly, Shorea contorta had the highest importance values among all sampled plots. This species is endemic in the Philippines which can be utilized in future conservation strategies. Milan (2010) said that the use of indigenous tree species to increase biodiversity and expansion of forest habitat significantly contribute in strengthening the forestry capacity in order to adapt on the impacts of climate change by enhancing ecosystem services and establishing protection of multiple environmental and social benefits. It is interesting to note that most of the species are dipterocarps, however, it becomes challenging in terms of conservation and protection. Extreme commercial logging has destroyed a considerable number of dipterocarp forests. In the Philippines, both legal and illegal logging are the most serious threat to forest ecosystems (Liu et al. 1993). These operations have continued because of poor law enforcement and increasing demand for timber and wood products.

Aside from dipterocarps, members of Moraceae are also dominant in tropical rainforests. Particularly, Ficus species constitute a large proportion of floral diversity in most tropical rainforest within equatorial Asia (Hua 2008). Cottee-Jones et al. (2016) reiterated the importance of Ficus trees for the restoration of tropical forests. These species are critically important in all tropical ecosystems. They produce large amount of fruits which serves as food and attract seed dispersers like birds and mammals. By this, seeds are dispersed suggesting that Ficus trees support regeneration of plant communities that are representative of the general landscape. Corbin and Holl (2012) also added that this characteristic is important in forest restoration and can produce assemblages of novel compositional structure. 
In the study of Geneme et al. (1987), a higher density of seedlings represents a successful regeneration. It is important to produce seedlings that retain their high quality to establish them quickly in the forest regeneration site. The gaps in the canopy in tropical lowland montane rainforest as observed in the field allow much light to reach the forest floor in the tropical lowland evergreen rainforest types and do not limit light penetration, thus, it favors germination of seeds which is light demanding (Denslow 1995) unlike in the tropical lower montane rainforest where the relatively closed canopy limits the amount of light reaching the forest floor and hence fewer seeds are germinating (Uhl and Clark 1983). Community structure of trees in forests may vary due to changes in individuals at low diameter size and height classes or exploitation of individuals. This means that community structure change is a function of regeneration pattern of individuals (Cunningham 2001). It is also noteworthy that community structure of trees is affected by anthropogenic and natural factors (Moles and Westoby, 2004). Limited number of mature and large trees in forest ecosystem may indicate that this growth form is extracted and utilized mostly by locals. This indication might not be the case of the two forest types assessed in this study. There are no traces or history of anthropogenic disturbance and seedlings and saplings are growing in large number. Nonetheless, information on tree species structure and function provide baseline information for conservation of the biodiversity of tropical forests (Ifo et al. 2016).

As a protected area, the maximal number of saplings in two forest types in Mt. Apo Natural Park favored regeneration. Tropical lowland evergreen rainforest, based on the proportion of seedlings, sapling, and trees, can regenerate more than tropical lower montane rainforest. According to Jones et al. (1994), the forest composition depends on the potential regenerative status of species composing the forest stand, in space and time. Regeneration of forest is essential as it addresses mainstream biodiversity adherence. It is the act of renewing tree cover by establishing young trees naturally or artificially, promptly after the previous stand or forest has been removed and maintains the species development and stocking after disturbances. Forest regeneration includes practices such as changes in tree density through; (i) human-assisted natural regeneration; (ii) enrichment planting; (iii) reduced grazing of forested savannas; and (iv) changes in tree provenances/genetics or tree species (IPCC 2007). The ratio of various age groups in different populations determines the reproductive status of the community and indicates the future course of the forest vegetation (Singh et al. 2007; Manral et al. 2018).

Comparatively, the tropical lowland evergreen rainforest supported greater diversity of plant communities as compared to tropical lower montane rainforest. Tropical lowland evergreen rainforest can regenerate more than tropical lower montane rainforest based on the densities of seedlings, saplings and trees. Assessment and analysis of diversity and community structure of tropical forest is important for their sustainable utilization, management, and conservation and provide baseline information in developing priorities for conservation purposes.

\section{ACKNOWLEDGEMENTS}

The researchers would like to extend their appreciation to those individuals, groups and institutions especially to the University of Southern Mindanao, Kabacan and Provincial Environment and Natural Resources Office, Kidapawan City, Cotabato, Philippines.

\section{REFERENCES}

Armenteras D, Rodriguez N, Retana J. 2009. Are conservation strategies effective in avoiding the deforestation of the Colombian Guyana Shield? Biol Conserv 142: 1411-1419.

Ashton P. 1988. Dipterocarp biology as a window to the understanding of tropical forest structure. Annu Rev Ecol Syst 19: 347-370.

Baraloto C, Paine CET, Patiño S, Bonal D, Herault B, Chave J. 2013. Functional trait variation and sampling strategies in species-rich plant communities. Funct Ecol 24: 208-216

Singh B, Gill R, Kaur N. 2007. Litterfall and nutrients return in poplar plantation varying in row directions and spacings. Indian J Agrof 9 (1): 33-37.

Corbin JD, Holl KD. 2012. Applied nucleation as a forest restoration strategy. For Ecol Manage 265: 37-46.

Cottee-Jones HEW, Bajpai O, Chaudhary LB, Whittaker RJ. 2016. The importance of Ficus (Moraceae) trees for tropical forest restoration. Biotropica 48 (3): 413-419.

Cunningham AB. 2001. Applied Ethnobotany. People Wild Plant Use and Conservation. EarthScan Publications Ltd., London.

Denslow JS. 1995. Disturbance and Diversity in Tropical Rainforests: The Density Effect. Ecol Appl 5: 962-968.

DENR. 2016. Updated National List of Threatened Philippine Plants and their Categories. DAO-2017-11. Department of Environmental and Natural Resources, Philippines. https: //www.philippineplants.org/dao-2017-11.pdf

Djuikouo MNK, Doucet JL, Nguembou CK, Lewis SL, Sonké B. 2010. Diversity and aboveground biomass in three tropical forest types in the Dja Biosphere Reserve, Cameroon. Afr J Ecol 48 (4): 1053-1063.

Elourard C, Pascal JP, Pelissier R, Pascal JP, Durand M, Aravajy S, Moravie MA, Gimaret-Carpentier C, Ramesh BR. 1997. Monitoring the structure and dynamics of a dense moist evergreen forest in the Western Ghats (Kodagu District, Karnataka, India). Trop Ecol 38: 193-214.

Fernando E, Min Hwan S, Jaeho L, Don Koo L. 2008. Forest Formations of the Philippines. ASEAN-Korea Environmental Cooperation Unit, Seoul.

Gavin D, Peart D. 1997. Spatial structure and regeneration of Tetramerista glabra in peat swamp rain forest in Indonesian Borneo. Plant Ecol 131 (2): 223-231.

Geneme ML, Rai JPN, Tripathi RS. 1987. Population structure of some tree species in disturbed and protected sub-tropical forests of northeast India. Acta Oecol-Oecol Appl 8 (3): 247-255.

Gentry A. 1988. Tree species richness of upper Amazonian forests. Proc Natl Acad USA 85: 156- 159.

Guedje NM, Lejoly J, Nkongmeneck BA, Jonkers WJ. 2013. Population dynamics of Garcinia lucida (Clusiaceae) in Cameroonian Atlantic forests. Forest Ecol Manag 177: 231-241.

Hua Z. 2008. Advances in biogeography of the tropical rain forest in southern Yunnan, southwestern China. Trop Conserv Sci 1 (1): 3442.

Ifo SA, Moutsambote JM, Koubouana F, Yoka J, Ndzai SF, BouetouKadilamio LNO, Mampouya H, Jourdain C, Bocko Y, Mantota AB, Mbemba, M. 2016. Tree species diversity, richness, and similarity in intact and degraded forest in the tropical rainforest of the Congo Basin: case of the forest of Likouala in the Republic of Congo. Int $\mathbf{J}$ Forest Res DOI: 10.1155/2016/7593681

IPCC. 2007. Intergovernmental Panel on Climate Change. The Nobel Foundation. IPCC-Sec@wmo.int 
Jones RH, Sharitz RR, Dixon PM, Segal DS, Schneider RL.1994. Woody plant regeneration in four flood plants forests. Ecol Monogr 64: 345367.

Kent KM, Coker P. 1992. Vegetation description and analysis. Belhaven Press, London UK.

Liu D, Iverson L, Brown S. 1993. Rates and patterns of deforestation in the Philippines: application of geographic information. For Ecol Manag 57: 1-16

Manral V, Padalia K, Karki H. 2018. Plant diversity and regeneration potential of three different forests of Central Himalaya. Curr World Environ 13 (1): 113.

Milan P. 2010. Abaca and rainforestation farming: A guide to sustainable farm management. Visayas State University, Baybay.

Moles AT, Westoby M. 2004. Seedling survival and seed size: a synthesis of the literature. J Ecol 92 (3): 372-383.

Mongabay DG. 2013. Tree regeneration in a subtropical humid forest: Effect of cultural disturbance on seed production, dispersal and germination. J Appl Ecol 33: 1551-1560.

Myers N, Mittermeier RA, Mittermeier CG, da Fonseca GAB, Kent J. 2000. Biodiversity hotspots for conservation priorities. Nature 40 (3) 853-858.

Rawat B. 2014. Changes in vegetation diversity and plant responses in Nanda Devil Biosphere Reserve over the last two decades. [Dissertation]. Submitted to Kumaun University Nainital, Uttarakhand. [Indian].
Rojo JP. 1992. Revised Lexicon of Philippine Trees. Forest Products Research and Development Institute, Department of Science and Technology, Taguig City.

Rojo JP, Aragones EG. 1997. Botanical Identification Handbook on Philippine Dipterocarps. Forest Products Research and Development Institute, Department of Science and Technology, Laguna, Philippines.

Saxena AK, Singh JS. 1984. Tree population structure of certain Himalayan forest associations and implications concerning their future composition. Vegetation 58: 61-69.

Ssegawa P, Nkuutu D. 2006. Diversity of vascular plants on Ssese Islands in Lake Victoria, Central Uganda. Afr J Ecol 44: 22-29.

Taubert F, Jahn MW, Dobner HJ, Wiegand T, Huth A. 2015. The structure of tropical forests and sphere packings. Proc Natl Acad Sci USA 112 (49): 15125-15129.

Tilman D. 1988. Plant Strategies and The Dynamics and Structure of Plant Communities. Princeton University Press, Princeton, New Jersey.

Trichon V. 1997. Hétérogénéité spatiale d'une forêt tropicale humide de Sumatra: effet de la topographie sur la structure floristique. Annales des Sciences Forestières, INRA/EDP Sciences 54 (5): 431-446.

Uhl C, Clark K. 1983. Seed ecology of selected Amazon Basin successional species. Bot Gaz 144: 419- 425.

WWF. 1986. Forests and Climate Change. World Wildlife Forest, Nederland. http:

//d2ouvy59p0dg6k.cloudfront.net/downloads/d_free_and_redd_brief_ cop21.pdf 